\title{
Effect of Smoking on Appetite, Concentration and Stress Level
}

\author{
Ahmed Awad ${ }^{1}$, Atef Obayan ${ }^{1}$, Suzana Salhab $^{1}$, Rabih Roufayel ${ }^{2} \&$ Seifedine Kadry $^{3}$ \\ ${ }^{1}$ Department of biological sciences, Faculty of sciences, Beirut Arab University, Lebanon \\ ${ }^{2}$ Department of Molecular and Cellular Biology, University of Guelph, Guelph, Ontario, Canada \\ ${ }^{3}$ Department of mathematics and computer science, Faculty of sciences Beirut Arab University, Lebanon \\ Correspondence: Seifedine Kadry, Faculty of Science, Beirut Arab University, Beirut, Lebanon. E-mail: \\ s.kadry@bau.edu.lb
}

Received: June 18, 2019 Accepted: October 28, 2019 Online Published: December 29, 2019

doi:10.5539/gjhs.v12n1p139 URL: https://doi.org/10.5539/gjhs.v12n1p139

\begin{abstract}
Objective: Smokers often report that cigarette relieve feeling of stress, improve mood and concentration and can decrease their appetite level. To identify weather a cigarette is a mood altering and appetite suppressant we study the effect of smoking on concentration, stress and appetite level among smokers.

Design: We examined if there is a relation between smoking and other variables (age, gender and working hours per week). Several data collected in the form of surveys from smokers and non-smokers and then analyzed using a software program SPSS.
\end{abstract}

Main outcome: Results according to smoker's majority shows that cigarette decrease their stress level and it has been shown that it's the most affected parameters compared to concentration and appetite level that are affected also by smoking.

Results: The results of this study show that smoking is related to age and it is affected by the number of working hours. Participants aged between 14 and 35 years, that include students, unemployed and hard-workers smoke the most and have the highest number of cigarettes per week.

Conclusion: Based on our study, smoking has an effect on appetite, concentration and stress that is correlated with working hours.

Keywords: Appetite, Concentration, Stress Level, Smoking,

\section{Introduction}

Smoking is considered to be a lifestyle practice in which a substance is burned, and the resulting smoke enters a living body's system and absorbed into the blood vessels. It is a common behavior nowadays and is becoming a major habit that affects the lifestyle of many individuals. The burnt substance is made from dried plant leaves, rolled using rice paper in a cylindrical form structure called cigarette (Lindson et al., 2019). Each cigarette contains a mixture of aerosol particles and gasses in addition to a pharmacological alkaloid called nicotine, which is considered to be a highly addictive substance (Kassel, 2000; Arnson et al., 2010). The vaporized combustion of the dried plant leaves produces actives substances in the lungs to be later absorbed into the bloodstream and different body tissues. Each cigarette contains more than 4,000 different chemicals, many of which are toxic and cause health hazards (Ditchburn \& Sellman, 2013). While most people are aware of the side effects of cigarette smoking, this bad habit is difficult to break.

Health hazards associated with smoking are illustrated in a form of critical diseases such as: chronic lung and airways disease, cardiovascular diseases, multiple sclerosis, lung cancer as well as other types cancers (World Health Organization, 2001; Nasim et al., 2019; Wang et al., 2019; Sundstrom et al., 2008). Although most people are aware of the hazards for smoking through advertising, conferences and other like school/university presentations, there has not been a significant decline in the number of smokers.

Many studies showed that most people who tend to use cigarette, smoke to control their concentration level and negative emotions like stress reduction. According to a survey study of adolescent smokers, the most frequently mentioned reasons for cigarette smoking were stress reduction and relaxation. Besides, many studies show the relation between smoking and appetite loss in reference to nicotine as an appetite suppressant (Slopen et al., 2013; 
Choi et al., 2015; Dozois et al., 1995, Nichter et al., 1997). To address whether cigarette smoking actually has an effect on reducing stress, increase in concentration and decrease in appetite, we select our sample using simple random sample (SRS) and relate them to many factors including gender, age and working hours.

\section{Methods and Data Collection}

The data was collected over two weeks from three different regions: Shouf, Saida and Tyr targeting smokers and non-smokers. The participants of the study were aged between 14 and 74 years. The main aim of these observations and survey is to show the relation between smoking and appetite, concentration, and stress. A total of 141 persons participated in the study and were asked to answer a 23 questions survey including multiple choices and yes/no questions. The variables were set according to the person's social life and mood. The survey consists on the following variables in Table 1.

Table 1. The main variables of the research like: gender, age, work, mood and smoking were compared in general. In addition to the relation between social life and smoking, mood can also interfere as one of the main reasons in smoking habit and addiction to it

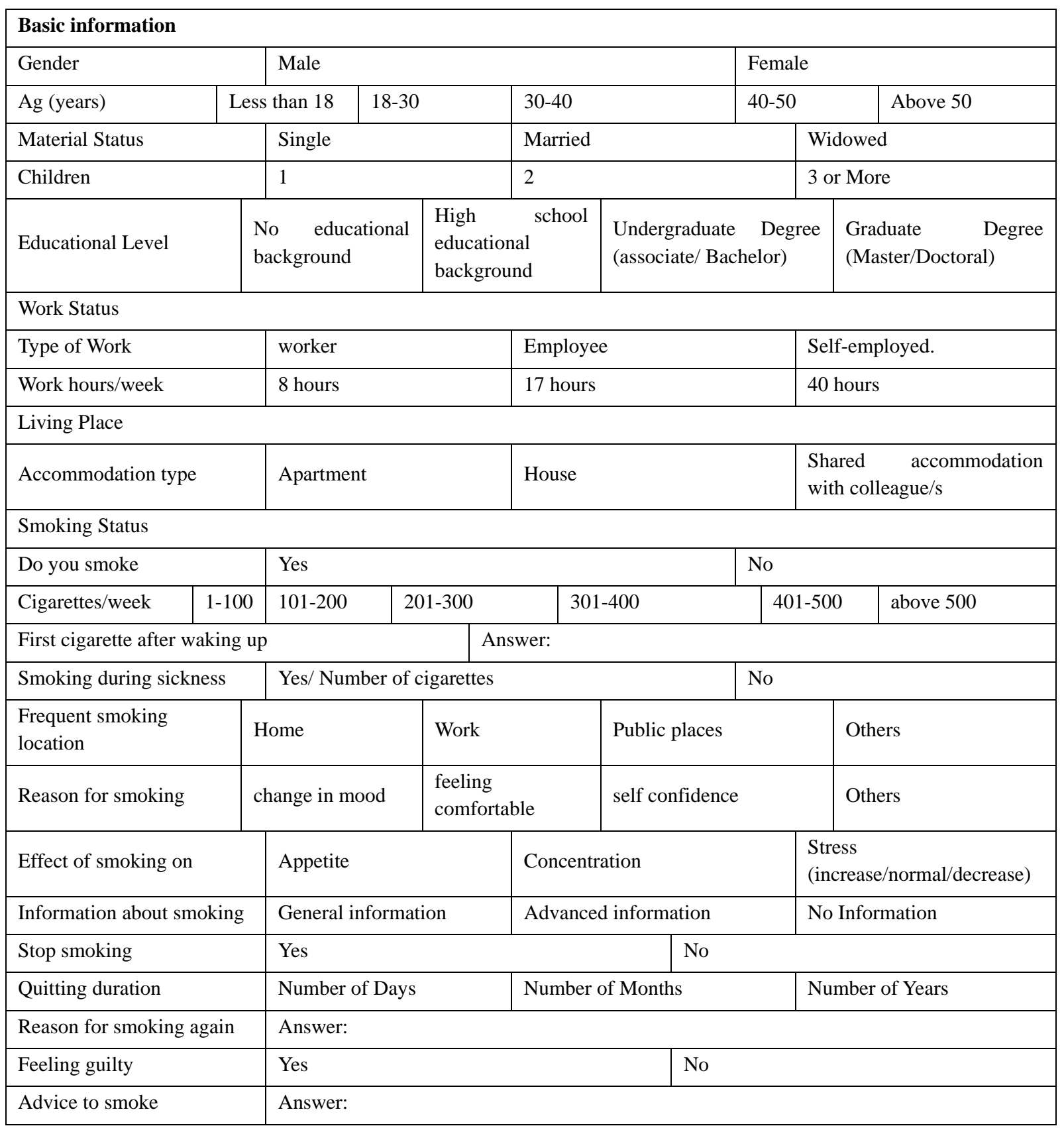




\section{Results}

\subsection{Descriptive Statistics}

Before testing other variables, we detect the number of smokers in the two Gender (Figure 1), according to their age (Figure 2) and work hours per week (Figure 3).

\section{Gender}

\begin{tabular}{|c|c|c|c|c|c|}
\hline \multicolumn{6}{|c|}{ Do you smoke * Gender Cross tabulation } \\
\hline \multicolumn{6}{|l|}{ Count } \\
\hline & & & \multicolumn{2}{|c|}{ Gender } & \multirow[b]{2}{*}{ Total } \\
\hline & & & Male & female & \\
\hline \multirow[t]{2}{*}{ Do you smoke } & \multicolumn{2}{|l|}{ Yes } & 79 & 25 & 104 \\
\hline & \multicolumn{2}{|l|}{ No } & 20 & 17 & 37 \\
\hline \multicolumn{3}{|l|}{ Total } & 99 & 42 & 141 \\
\hline \multicolumn{6}{|l|}{ Chi-Square Tests } \\
\hline & Value & $\mathrm{df}$ & $\begin{array}{l}\text { Asymptotic } \\
\text { Significance } \\
\text { (2-sided) }\end{array}$ & Exact Sig. (2-sided) & Exact Sig. (1-sided) \\
\hline Pearson Chi-Square & $6.263^{\mathrm{a}}$ & 1 & .012 & & \\
\hline Continuity Correction $^{\mathrm{b}}$ & 5.259 & 1 & .022 & & \\
\hline Likelihood Ratio & 5.986 & 1 & .014 & & \\
\hline Fisher's Exact Test & & & & .020 & .012 \\
\hline Linear-by-Linear Association & 6.218 & 1 & .013 & & \\
\hline $\mathrm{N}$ of Valid Cases & 141 & & & & \\
\hline
\end{tabular}

a. 0 cells $(.0 \%)$ have expected count less than 5 . The minimum expected count is 11.02.

b. Computed only for a $2 \times 2$ table.

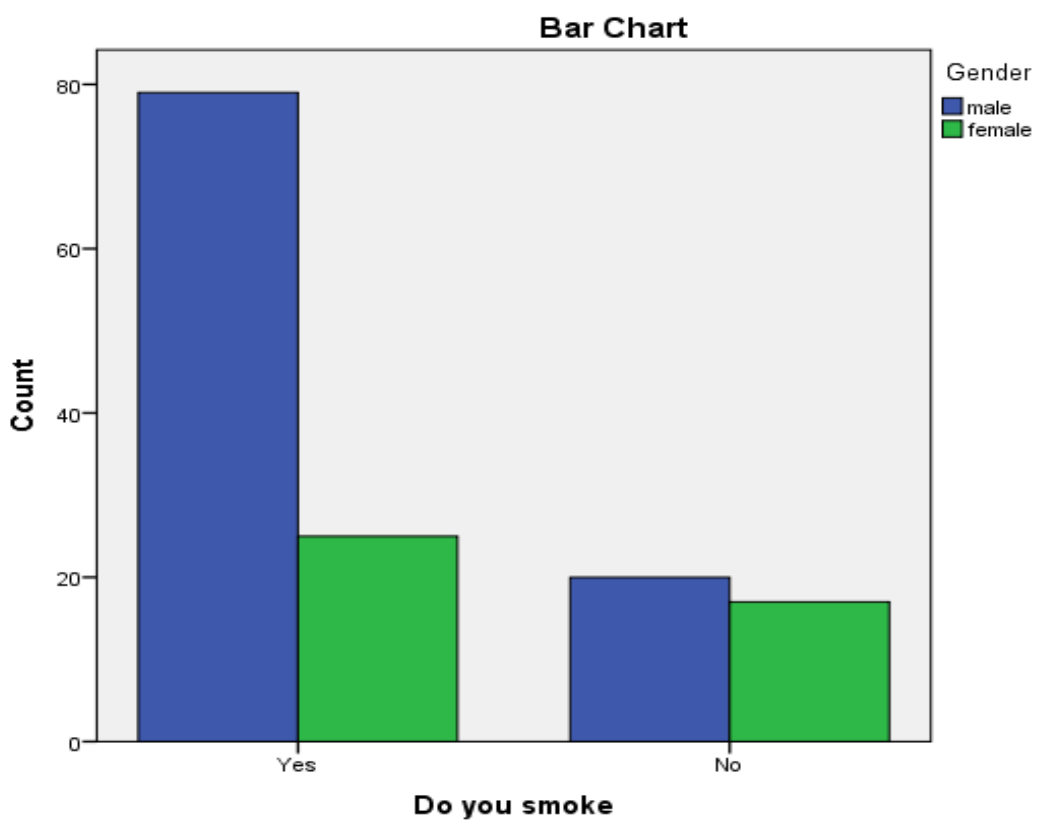

Figure 1. Relation between smoking and gender 
Among 141 participants (99 male and 42 female), $79.79 \%$ of male smoke, while $59.52 \%$ of female smoke.

Age

\begin{tabular}{|c|c|c|c|c|c|c|c|c|}
\hline \multicolumn{9}{|c|}{ Do you smoke * Age Cross tabulation } \\
\hline \multicolumn{9}{|l|}{ Count } \\
\hline & & \multicolumn{6}{|c|}{ Age } & \multirow[b]{2}{*}{ Tota } \\
\hline & & $(14-24)$ & $(25-35)$ & $(36-46)$ & $(47-57)$ & $(58-68)$ & (above 68) & \\
\hline \multirow[t]{2}{*}{ Do you smoke } & Yes & 56 & 28 & 11 & 4 & 4 & 1 & 104 \\
\hline & No & 22 & 2 & 3 & 3 & 7 & 0 & 37 \\
\hline \multicolumn{2}{|l|}{ Total } & 78 & 30 & 14 & 7 & 11 & 1 & 141 \\
\hline
\end{tabular}

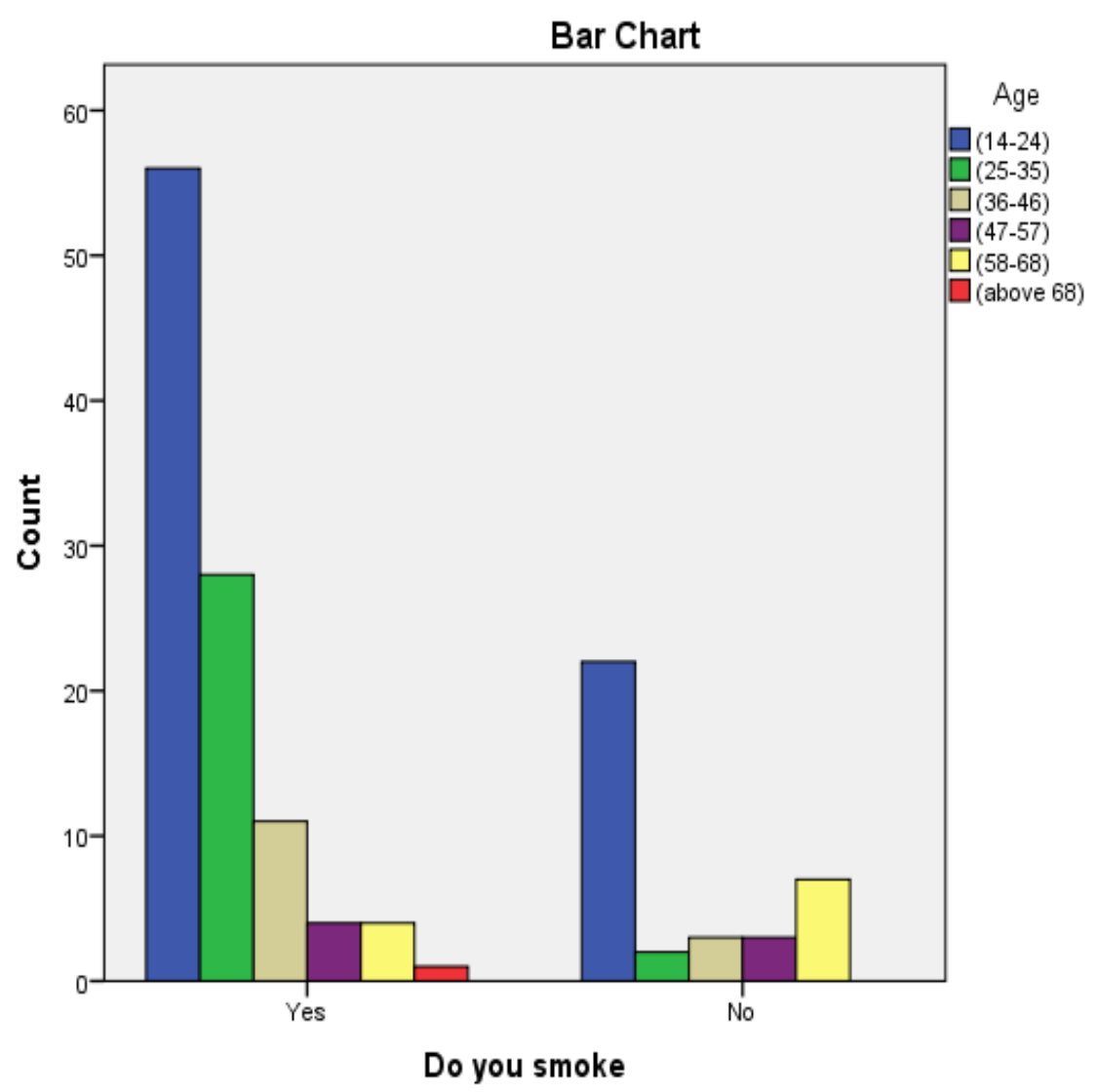

Figure 2. Relation between smoking and age

$71.79 \%$ of participants aged between 14 and 24 years smoke, while $93.33 \%$ of participants aged between 25 and 35 smoke. Between 36 and 46 years, $78.57 \%$ of participants smoke, while between 47 and 57 years, $57.14 \%$ smoke. Between 58 and 74 years, only $33.33 \%$ of participants smoke. 


\section{Work hours per week}

\begin{tabular}{|c|c|c|c|c|c|c|c|c|}
\hline \multicolumn{9}{|c|}{ Do you smoke * work hours/week Crosstabulation } \\
\hline \multicolumn{9}{|l|}{ Count } \\
\hline & & \multicolumn{7}{|c|}{ work hours/week } \\
\hline & & $(0-12)$ & $(13-25)$ & $(26-38)$ & $(39-51)$ & $(52-64)$ & $(65-77)$ & Total \\
\hline \multirow[t]{2}{*}{ Do you smoke } & Yes & 48 & 14 & 10 & 12 & 9 & 11 & 104 \\
\hline & No & 21 & 3 & 8 & 5 & 0 & 0 & 37 \\
\hline Total & & 69 & 17 & 18 & 17 & 9 & 11 & 141 \\
\hline
\end{tabular}

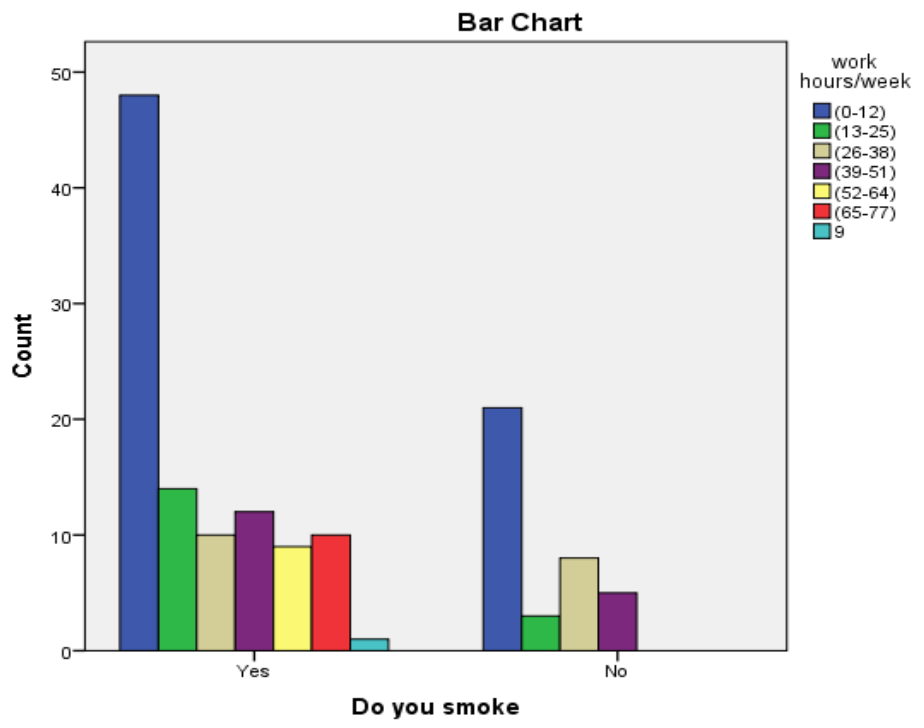

Figure 3. Relation between smoking and work hours per week

$70.58 \%$ of participants working between 0 to 12 hours smoke, while $82.35 \%$ of participants working between 13 to 25 hours smoke. Between 26 to 38 hours, $55.55 \%$ of participants smoke, while between 39 to 51 hours, $70.58 \%$ smoke. Between 52 to 77 hours, all participants smoke.

\section{Age and work hours per week}

\begin{tabular}{|c|c|c|c|c|c|c|c|c|}
\hline \multicolumn{9}{|c|}{ work hours/week $*$ Age Crosstabulation } \\
\hline \multicolumn{9}{|c|}{ Count } \\
\hline & & \multicolumn{6}{|c|}{ Age } & \multirow[b]{2}{*}{ Total } \\
\hline & & $(14-24)$ & $(25-35)$ & $(36-46)$ & $(47-57)$ & $(58-68)$ & (above 68) & \\
\hline \multirow[t]{6}{*}{ work hours/week } & $(0-12)$ & 53 & 7 & 5 & 1 & 2 & 1 & 69 \\
\hline & $(13-25)$ & 9 & 5 & 1 & 2 & 0 & 0 & 17 \\
\hline & $(26-38)$ & 7 & 4 & 1 & 2 & 4 & 0 & 18 \\
\hline & $(39-51)$ & 2 & 6 & 3 & 2 & 4 & 0 & 17 \\
\hline & $(52-64)$ & 1 & 4 & 3 & 0 & 1 & 0 & 9 \\
\hline & $(65-77)$ & 6 & 4 & 1 & 0 & 0 & 0 & 11 \\
\hline \multicolumn{2}{|l|}{ Total } & 78 & 30 & 14 & 7 & 11 & 1 & 141 \\
\hline
\end{tabular}

Figure 4. Relation between age and work hours per week 
Participants that smoke 1 to 100 cigarettes per week have the highest percentage, while participants that smoke above 500 cigarettes per week have the lowest percentage.

\begin{tabular}{|c|c|c|c|c|c|}
\hline \multicolumn{6}{|c|}{ Cigarettes/week } \\
\hline & & Frequency & Percent & Valid Percent & Cumulative Percent \\
\hline \multirow{7}{*}{ Valid } & $(1-100)$ & 40 & 28.4 & 39.6 & 39.6 \\
\hline & $(101-200)$ & 32 & 22.7 & 31.7 & 71.3 \\
\hline & $(201-300)$ & 17 & 12.1 & 16.8 & 88.1 \\
\hline & $(301-400)$ & 3 & 2.1 & 3.0 & 91.1 \\
\hline & $(401-500)$ & 7 & 5.0 & 6.9 & 98.0 \\
\hline & (above 500) & 2 & 1.4 & 2.0 & 100.0 \\
\hline & Total & 101 & 71.6 & 100.0 & \\
\hline Missing & System & 40 & 28.4 & & \\
\hline \multicolumn{2}{|l|}{ Total } & 141 & 100.0 & & \\
\hline
\end{tabular}

Figure 5a. Relation between numbers of cigarettes per week

\begin{tabular}{|l|l|c|c|c|c|}
\hline \multicolumn{2}{|c|}{ Stop smoking } \\
\hline \multirow{2}{*}{ Valid } & Frequency & Percent & Valid Percent & Cumulative Percent \\
\cline { 2 - 6 } & No & 56 & 39.7 & 55.4 & 55.4 \\
\cline { 2 - 6 } & Total & 45 & 31.9 & 44.6 & 100.0 \\
\hline \multirow{2}{*}{ Missing } & System & 101 & 71.6 & 100.0 & \\
\hline \multirow{2}{*}{ Total } & & 40 & 28.4 & & \\
\hline
\end{tabular}

Figure 5b. Relation between stop smoking activities

\begin{tabular}{|c|c|c|c|c|c|}
\hline \multicolumn{6}{|c|}{ Quitting duration } \\
\hline & & Frequency & Percent & Valid Percent & $\begin{array}{c}\text { Cumulative } \\
\text { Percent }\end{array}$ \\
\hline \multirow[t]{7}{*}{ Valid } & Less then 1 week & 17 & 12.1 & 29.8 & 29.8 \\
\hline & 1 week & 6 & 4.3 & 10.5 & 40.4 \\
\hline & 1 month & 14 & 9.9 & 24.6 & 64.9 \\
\hline & 3 months & 10 & 7.1 & 17.5 & 82.5 \\
\hline & More then 3 months & 9 & 6.4 & 15.8 & 98.2 \\
\hline & Forever & 1 & .7 & 1.8 & 100.0 \\
\hline & Total & 57 & 40.4 & 100.0 & \\
\hline Missing & System & 84 & 59.6 & & \\
\hline \multicolumn{2}{|l|}{ Total } & 141 & 100.0 & & \\
\hline
\end{tabular}

Figure 5c. Relation between quitting duration 


\begin{tabular}{|c|c|c|c|c|c|}
\hline \multicolumn{6}{|c|}{ Cause of smoking again } \\
\hline & & Frequency & Percent & Valid Percent & Cumulative Percent \\
\hline \multirow[t]{8}{*}{ Valid } & & 85 & 60.3 & 60.3 & 60.3 \\
\hline & because of surroundings & 4 & 2.8 & 2.8 & 63.1 \\
\hline & I couldn't resist & 25 & 17.7 & 17.7 & 80.9 \\
\hline & No reason & 6 & 4.3 & 4.3 & 85.1 \\
\hline & personal reason & 7 & 5.0 & 5.0 & 90.1 \\
\hline & to decrease stress & 13 & 9.2 & 9.2 & 99.3 \\
\hline & to decrease appetite & 1 & .7 & .7 & 100 \\
\hline & Total & 141 & 100.0 & 100.0 & \\
\hline \multicolumn{6}{|c|}{ Chi-Square Tests } \\
\hline & Value & $\mathrm{df}$ & \multicolumn{3}{|c|}{ Asymptotic Significance (2-sided) } \\
\hline Pearson Chi-Square & $27.562^{\mathrm{a}}$ & 2 & \multicolumn{3}{|c|}{0.000001} \\
\hline Likelihood Ratio & 39.351 & 2 & \multicolumn{3}{|c|}{$2.8515 \mathrm{E}-9$} \\
\hline Linear-by-Linear Association & 12.830 & 1 & \multicolumn{3}{|c|}{0.000341} \\
\hline $\mathrm{N}$ of Valid Cases & 141 & & & & \\
\hline
\end{tabular}

Figure 5d. Relation between returning back to smoking

$55.4 \%$ of participants stop smoking. $82.5 \%$ of them smoked again within 3 months, while only $1.8 \%$ quit forever. Among participants that smoked again, $17.7 \%$ didn't resist.

\section{Smoking and mood}

We detect the relation of smoking and mood that includes appetite, concentration and stress (Figure 6).

\section{Smoking and appetite}

Does smoking cause a change in appetite level?

$\mathrm{H}_{0}$ : Smoking doesn't change in appetite level

$\mathrm{H}_{\mathrm{a}}$ : Smoking cause a change in appetite level

According to the chi-square test the $\mathrm{p}$-value $=0.000001$ and when the $\mathrm{p}$-value is lower than 0.05 its considered significant. Therefore we accept the $\mathrm{H}_{\mathrm{a}}$ and reject $\mathrm{H}_{0}$.

So we conclude that smoking cause change in appetite level.

\section{Smoking and concentration}

Does smoking cause a change in concentration level?

$\mathrm{H}_{0}$ : Smoking doesn't change in concentration level

$\mathrm{H}_{\mathrm{a}}$ : Smoking cause a change in concentration level

According to the chi-square test the $\mathrm{p}$-value $=0.000017$ and when the $\mathrm{p}$-value is lower than 0.05 its considered significant. Therefore we accept the Ha and reject $\mathrm{H} 0$.

So we conclude that smoking cause change in concentration level.

\section{Smoking and stress}

Does smoking cause a change in stress level?

$\mathrm{H}_{0}$ : Smoking doesn't change in stress level

$\mathrm{H}_{\mathrm{a}}$ : Smoking cause a change in stress level

According to the chi-square test the $\mathrm{p}$-value $=0.00005$ and when the $\mathrm{p}$-value is lower than 0.05 its considered significant. Therefore we accept the $\mathrm{H}_{\mathrm{a}}$ and reject $\mathrm{H}_{0}$. 
So we conclude that smoking cause change in stress level.

\begin{tabular}{|c|c|c|c|c|c|c|}
\hline \multicolumn{7}{|l|}{ Appetite } \\
\hline & & \multicolumn{2}{|l|}{ Frequency } & Percent & Valid Percent & Cumulative Percent \\
\hline \multirow[t]{4}{*}{ Valid } & Increase & \multicolumn{2}{|l|}{6} & 4.3 & 5.9 & 5.9 \\
\hline & Normal & \multicolumn{2}{|l|}{51} & 36.2 & 50.5 & 56.4 \\
\hline & Decrease & 44 & & 31.2 & 43.6 & 100.0 \\
\hline & Total & \multicolumn{2}{|c|}{101} & 71.6 & 100.0 & \\
\hline Missing & System & 40 & & 28.4 & & \\
\hline \multicolumn{2}{|l|}{ Total } & 141 & & 100.0 & & \\
\hline \multicolumn{7}{|c|}{ Chi-Square Tests } \\
\hline & & & \multicolumn{2}{|l|}{ Value } & \multicolumn{2}{|c|}{ Asymptotic Significance (2-sided) } \\
\hline \multicolumn{2}{|c|}{ Pearson Chi-Square } & & $22.010^{\mathrm{a}}$ & 2 & \multicolumn{2}{|r|}{0.000017} \\
\hline \multicolumn{2}{|c|}{ Likelihood Ratio } & & 32.390 & 2 & \multicolumn{2}{|r|}{$9.2599 \mathrm{E}-8$} \\
\hline \multicolumn{3}{|c|}{ Linear-by-Linear Association } & 12.611 & 1 & \multicolumn{2}{|r|}{0.000383} \\
\hline \multicolumn{3}{|c|}{$\mathrm{N}$ of Valid Cases } & 141 & & & \\
\hline
\end{tabular}

a. 2 cells (33.3\%) have expected count less than 5. The minimum expected count is 1.05.

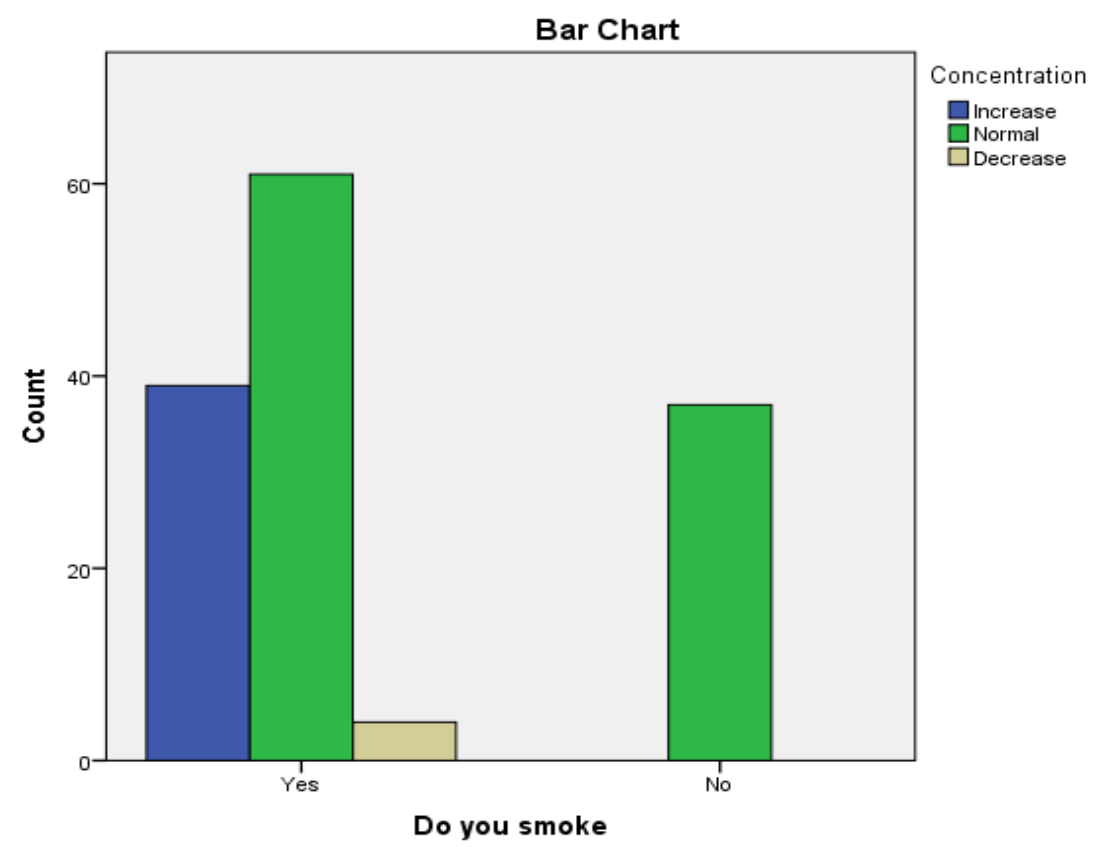

Figure 6a. Relation between smoking and appetite

\begin{tabular}{|c|c|c|c|c|c|}
\hline \multicolumn{6}{|c|}{ Concentration } \\
\hline \multirow{5}{*}{ Valid } & & Percent & Valid Percent & \multicolumn{2}{|c|}{ Cumulative Percent } \\
\hline & Increase & 39 & 27.7 & 38.6 & 38.6 \\
\hline & Normal & 58 & 41.1 & 57.4 & 96.0 \\
\hline & Decrease & 4 & 2.8 & 4.0 & 100.0 \\
\hline & Total & 101 & 71.6 & 100.0 & \\
\hline Missing & System & 40 & 28.4 & & \\
\hline \multicolumn{2}{|c|}{ Total } & 141 & 100.0 & & \\
\hline
\end{tabular}




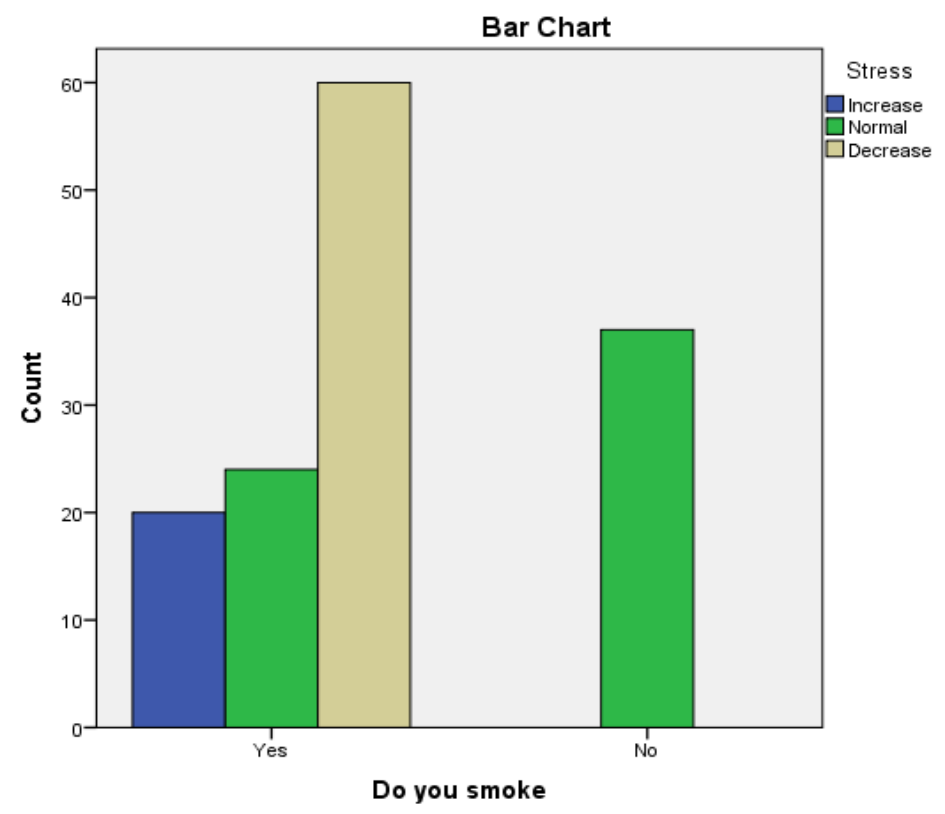

Figure 6b. Relation between smoking and concentration

\begin{tabular}{|c|c|c|c|c|c|c|c|}
\hline \multicolumn{8}{|c|}{ Stress } \\
\hline & & Frequency & \multicolumn{2}{|c|}{ Percent } & \multicolumn{2}{|c|}{ Valid Percent } & Cumulative Percent \\
\hline \multirow[t]{4}{*}{ Valid } & Increase & 20 & & 14.2 & & 19.8 & 19.8 \\
\hline & Normal & 21 & & 14.9 & & 20.8 & 40.6 \\
\hline & Decrease & 60 & & 42.6 & & 59.4 & 100.0 \\
\hline & Total & 101 & & 71.6 & & 100.0 & \\
\hline Missing & System & 40 & & 28.4 & & & \\
\hline \multicolumn{2}{|l|}{ Total } & 141 & & 100.0 & & & \\
\hline \multicolumn{8}{|c|}{ Chi-Square Tests } \\
\hline & & \multicolumn{2}{|c|}{ Value } & \multicolumn{2}{|c|}{ df } & \multicolumn{2}{|c|}{ Asymptotic Significance (2-sided) } \\
\hline \multicolumn{2}{|c|}{ Pearson Chi-Square } & \multicolumn{2}{|c|}{$65.788^{\mathrm{a}}$} & & 2 & \multicolumn{2}{|r|}{$5.1795 \mathrm{E}-15$} \\
\hline \multicolumn{2}{|c|}{ Likelihood Ratio } & \multicolumn{2}{|c|}{80.537} & & 2 & \multicolumn{2}{|r|}{$3.248 \mathrm{E}-18$} \\
\hline \multicolumn{2}{|c|}{ Linear-by-Linear Association } & \multicolumn{2}{|c|}{8.233} & & 1 & \multicolumn{2}{|r|}{0.004114} \\
\hline \multicolumn{2}{|c|}{$\mathrm{N}$ of Valid Cases } & \multicolumn{2}{|r|}{141} & & & & \\
\hline
\end{tabular}

a. 0 cells $(.0 \%)$ have expected count less than 5 . The minimum expected count is 5.25.

Figure 6c. Relation between smoking and stress

Among smoker participants, are others whom their appetite level said to be normal. In contrast to it, a high number of smokers, have shown a decrease in their appetite level. However, concentration level for smokers varies between increasing and normal. Additionally, stress have marked a decreasing level.

\section{Discussion}

The results of this study show that smoking is related to age and it is affected by the number of working hours. Concerning age, participants aged between 14 and 35 years, that include students and unemployed (0 to 12 hours/week), and hard-workers (52 to 77 hours/week), smoke the most and have the highest number of cigarettes per week. On the other hand, many parameters were taken into consideration for smokers, such as marital status, children, type of work, etc., data showed that their number of cigarettes smoked per week are more compared to other situation (Data not shown). Furthermore, 55.4\% of smokers tried to stop smoking for feeling guilty but only 
$1.8 \%$ of this population understudy were able to quit. However, the highest majority around $82.5 \%$ smoked again within 3 months since they are addicted to the irresistible nicotine showing that smoking is a key manipulator of stress.

\section{Conclusion}

Based on our study, smoking has an effect on appetite, concentration and stress. Among participants, appetite level in reference to smokers range between normal and decreasing when smoking, whereas concentration level of smokers ranges between increasing and normal. Concerning stress level, it significantly decreases among smokers. Hence, we conclude that smoking affects these three parameters, and especially stress.

\section{Competing Interests Statement}

The authors declare that there are no competing or potential conflicts of interest.

\section{References}

Arnson, Y., Shoenfeld, Y., \& Amital, H. (2010). Effects of tobacco smoke on immunity, inflammation and autoimmunity. Journal of autoimmunity, 34(3), J258-J265. https://doi.org/10.1016/j.jaut.2009.12.003

Choi, D., Ota, S., \& Watanuki, S. (2015). Does cigarette smoking relieve stress? Evidence from the event-related potential (ERP). International Journal of Psychophysiology, 98(3), 470-476. https://doi.org/10.1016/j.ijpsycho.2015.10.005

Ditchburn, K. M., \& Sellman, J. D. (2013). Tobacco Smoking in Adolescent Psychiatric Outpatients. Journal of Child \& Adolescent Substance Abuse, 22(3), 254-267. https://doi.org/10.1080/1067828X.2012.733598

Dozois, D. N., Farrow, J. A., \& Miser, A. (1995). Smoking patterns and cessation motivations during adolescence. International Journal of the Addictions, 30(11), 1485-1498. https://doi.org/10.3109/10826089509055844

Kassel, J. D. (2000). Are adolescent smokers addicted to nicotine? The suitability of the nicotine dependence construct as applied to adolescents. Journal of Child \& Adolescent Substance Abuse, 9(4), 27-49. https://doi.org/10.1300/J029v09n04_03

Lindson, N., Chepkin, S. C., Ye, W., Fanshawe, T. R., Bullen, C., \& Hartmann-Boyce, J. (2019). Different doses, durations and modes of delivery of nicotine replacement therapy for smoking cessation. Cochrane Database of Systematic Reviews, (4). https://doi.org/10.1002/14651858.CD013308

Nasim, F., Sabath, B. F., \& Eapen, G. A. (2019). Lung Cancer. Med Clin North Am, 103(3), 463-473. https://doi.org/10.1016/j.mena.2018.12.006

Slopen, N., Kontos, E. Z., Ryff, C. D., Ayanian, J. Z., Albert, M. A., \& Williams, D. R. (2013). Psychosocial stress and cigarette smoking persistence, cessation, and relapse over 9-10 years: a prospective study of middle-aged adults in the United States. Cancer Causes \& Control, 24(10), 1849-1863. https://doi.org/10.1007/s10552-013-0262-5

Sundström, P., Nyström, L., \& Hallmans, G. (2008). Smoke exposure increases the risk for multiple sclerosis. European journal of neurology, 15(6), 579-583. https://doi.org/10.1111/j.1468-1331.2008.02122.x

Wang, Z., Xie, J., Wu, C., \& Xiao, G. (2019). Correlation Between Smoking and Passive Smoking with Multiple Sclerosis and the Underlying Molecular Mechanisms. Medical science monitor: international medical journal of experimental and clinical research, 25, 893. https://doi.org/10.12659/MSM.912863

World Health Organization International Program on Chemical Safety. Biomarkers in Risk Assessment: Validity and Validation (World Health Organization, 2001).

\section{Copyrights}

Copyright for this article is retained by the author(s), with first publication rights granted to the journal.

This is an open-access article distributed under the terms and conditions of the Creative Commons Attribution license (http://creativecommons.org/licenses/by/4.0/). 